Original article

\title{
The role of the immune response mediator genes polymorphism in the predisposition to juvenile idiopathic arthritis
}

\author{
Liliia Sh. Nazarova ${ }^{1}$, Ksenia V. Danilko ${ }^{1}$, Viktor A. Malievsky ${ }^{1}$, Akhat B. Bakirov ${ }^{1,2}$, Tatiana V. Viktorova ${ }^{1,3}$ \\ ${ }^{1}$ Bashkir State Medical University, Ufa, Russia \\ ${ }^{2}$ Ufa Research Institute of Occupational Health and Human Ecology, Ufa, Russia \\ ${ }^{3}$ Institute of Biochemistry and Genetics, Ufa, Russia
}

Received 12 January 2019, Revised 3 May 2019, Accepted 8 August 2019

(C) 2019, Nazarova L.S., Danilko K.V., Malievsky V.A., Bakirov A.B., Viktorova T.V.

(C) 2019, Russian Open Medical Journal

Abstract: Objective - The aim of the work was to study the contribution of the immune response mediator genes polymorphism (TNFA rs1800629, LTA rs909253, IL1B rs16944, IL2-IL21 rs6822844, IL2RA rs2104286, IL6 rs1800795, IL10 rs1800872, MIF rs755622, CTLA4 rs3087243, NFKB1 rs28362491, PTPN22 rs2476601, PADI4 rs2240336) to the formation of the predisposition to juvenile idiopathic arthritis (JIA) and its clinical variants.

Material and Methods - The JIA group included 330 patients and the control group - 342 volunteers without autoimmune diseases from the Republic of Bashkortostan, Russia. Genotyping was conducted by the real-time polymerase chain reaction.

Results - Taking into account the differences by sex, it was established, that the alleles/genotypes of the TNFA rs1800629, LTA rs909253, IL2-IL21 rs6822844, PTPN22 rs2476601 polymorphic loci and the TNFA rs1800629*G - LTA rs909253*G haplotype are associated with the development of JIA as a whole (p<0.05); alleles/genotypes of the LTA rs909253, IL1B rs16944, IL2-IL21 rs6822844, IL2RA rs2104286, IL6 rs1800795, IL10 rs1800872, MIF rs755622, CTLA4 rs3087243, NFKB1 rs28362491, PTPN22 rs2476601 polymorphic loci and the TNFA rs1800629*G - LTA rs909253*G haplotype - with some of JIA clinical variants $(p<0.05)$.

Conclusion - In this work, the relationship of the alleles, genotypes and haplotypes of a number of the immune response mediator genes polymorphic loci with the risk of the development of JIA and its clinical variants was established. Specific associations were observed for girls and boys, which indicates the existence of sexual dimorphism in the JIA pathogenesis.

Keywords: juvenile idiopathic arthritis, predisposition, polymorphic loci, association, sexual dimorphism.

Cite as Nazarova LS, Danilko KV, Malievsky VA, Bakirov AB, Viktorova TV. The role of the immune response mediator genes polymorphism in the predisposition to juvenile idiopathic arthritis. Russian Open Medical Journal 2019; 8: e0408.

Correspondence to Liliia Sh. Nazarova. Address: 47, Zaki Validi Str., Ufa, 450077, Russia. Phone: +7 (347) 273-58-75. E-mail: lilinaz19@mail.ru.

\section{Introduction}

Juvenile idiopathic arthritis (JIA) is one of the most common chronic rheumatic diseases in children [1]. An important role in the JIA development is given to the immune response disorders, arising in genetically predisposed individuals [2-4].

Among the key mediators of the immune response, the cell surface molecules (including proteins of the major histocompatibility complex), pro- and anti-inflammatory cytokines, transcription factors, enzymes and other regulatory molecules can be particularly highlighted. Polymorphism, which is characteristic for many of the corresponding genes, causes pronounced interindividual variability, including the variability in the predisposition to JIA [2-4].

In recent years, a relatively large number of studies, including genome-wide association studies (GWAS), have been performed to detect the specific JIA risk markers. Nevertheless, the question is still open [3, 4]. Only for a small number of candidate genes polymorphic variants the association was confirmed in independent studies, and their total contribution to the explanation of the hereditary predisposition to JIA is rather small [3, 4]. In addition, the results of replicative studies are often contradictory, which may be due to a variety of factors, such as the use of different approaches for describing JIA phenotypes and for patients grouping, incorrect selection criteria and insufficient sample size, genotyping errors, and true population differences [4].

The aim of the work was to study the contribution of the immune response mediator genes polymorphism (TNFA rs1800629, LTA rs909253, IL1B rs16944, IL2-IL21 rs6822844, IL2RA rs2104286, IL6 rs1800795, IL10 rs1800872, MIF rs755622, CTLA4 rs3087243, NFKB1 rs28362491, PTPN22 rs2476601, PADI4 rs2240336) to the formation of the predisposition to JIA and its clinical variants.

\section{Material and Methods}

Study design and subjects

A case-control study was conducted. The study was approved by the expert council on biomedical ethics of Bashkir State Medical University (Ufa, Russia). The JIA group included 330 patients who 
underwent examination and treatment in the cardiorheumatological department of the Republican Children's Clinical Hospital in 2011-2017. The JIA diagnosis was established according to the International League of Associations for Rheumatology (ILAR) criteria [5]. The presented JIA clinical variants and their ratio in our sample are shown in Table 1. As a control group, 342 volunteers without autoimmune diseases were selected. All participants of the study (for the JIA group - parents of all patients) signed the voluntary informed consent. The age of the examined patients was $9.05(4.99,13.30)$ years, and of the controls - $18.00(18.00,19.00)$ years (data presented as median with low and upper quartiles). The ratio of males and females in the JIA and control groups was $34.24 \% / 65.76 \%$ and $30.99 \% / 69.01 \%$, respectively. All the individuals included in the study were residents of the Republic of Bashkortostan (Russia) and belonged to the following ethnic groups: Tatars (25.54\%), Russians $(21.72 \%)$, Bashkirs (13.13\%), mixed and others (39.62\%).

\section{Genotyping}

DNA isolation from the lymphocytes of the whole blood samples was performed using a standard phenol-chloroform method [6]. Genotyping of all the individuals for the 12 polymorphic loci (TNFA rs1800629, LTA rs909253, IL1B rs16944, IL2-IL21 rs6822844, IL2RA rs2104286, IL6 rs1800795, IL10 rs1800872, MIF rs755622, CTLA4 rs3087243, NFKB1 rs28362491, PTPN22 rs2476601, PADI4 rs2240336) was conducted by the realtime polymerase chain reaction (StepOnePlus ${ }^{\mathrm{TM}}$ Real-Time PCR System, Applied Biosystems, USA). Sequence-specific primers and allele-specific probes were designed and synthesized by the "DNKsyntez" company (Russia). The distribution of the polymorphic loci variants in patients with JIA and in the control group is shown in the Supplementary Tables 1-5 (Appendix 1).

\section{Statistical analysis}

Statistical processing of the results was carried out using Microsoft Excel, SNPStats, $R$ v.3.4.2, PowerMarker v.3.25, STATISTICA v.10 (StatSoft, Inc.) [7-9].

To compare the genotype and allele frequency distribution in the JIA patients group and in the control group the two-tailed Fisher's Exact test was used. The differences were considered statistically significant at $p<0.05$. A similar analysis was also performed separately for boys and girls and for specific clinical variants of the disease. The multiple testing correction of the $p$ values was carried out by applying a permutation test with a $10^{4}$ permutes $\left(p_{\text {cor }}\right)[7,10]$.

Table 1. Clinical characteristics of the JIA group

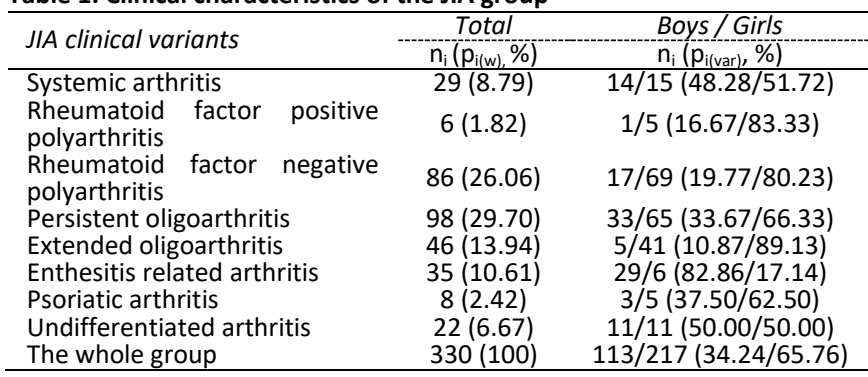

Hereinafter: $n_{i}$, number of patients in the groups; $p_{i}$, frequency; $p_{i(w)}$ frequency in the whole JIA group; $p_{i(v a r)}$, frequency in the corresponding JIA clinical variant group.
In addition, the odds ratio (OR) with the Baptista-Pike exact conditional $95 \%$ confidence interval $(95 \% \mathrm{Cl})$ were calculated [11].

Given that the TNFA and LTA genes are located in the same cluster on chromosome 6 , the linkage disequilibrium test for the TNFA rs1800629 and LTA rs909253 polymorphic loci was performed in the SNPStats package, which showed almost complete linkage disequilibrium at $99.94 \%\left(D=0.0807, D^{\prime}=0.9994\right.$, $r=0.5438, p=0.000$ ). Therefore, the haplotypes of these loci have also been studied as the potential risk markers for the development of JIA and its clinical variants.

Testing for the deviations from the Hardy-Weinberg equilibrium was carried out in the SNPStats package. There were no significant deviations from the Hardy-Weinberg equilibrium for the TNFA rs1800629, LTA rs909253, IL1B rs16944, IL2RA rs2104286, IL6 rs1800795, IL10 rs1800872, MIF rs755622, CTLA4 rs3087243, NFKB1 rs28362491, PTPN22 rs2476601, PADI4 rs2240336 polymorphic loci in both groups (JIA and control) ( $p>0.05$ ). A slight deviation from the Hardy-Weinberg equilibrium was established for the IL2-IL21 rs6822844 polymorphic locus in the control group $(p=0.019)$, but considering that the controls were selected according to the specified criteria (age, sex, the absence of autoimmune diseases), this locus was kept for the subsequent analysis.

\section{Results}

The established relationship of the alleles, genotypes and haplotypes of a number of the immune response mediator genes polymorphic loci with the risk of the development of JIA and its clinical variants is shown in the Table 2.

Taking into account the differences by sex, the risk predictors of the development of JIA as a whole were identified among the alleles/genotypes of the loci TNFA rs1800629 (for girls), LTA rs909253 (for boys), IL2-IL21 rs6822844 (for girls), PTPN22 rs2476601 (for girls), as well as among the haplotypes of the TNFA rs1800629 - LTA rs909253 loci (for boys). In addition, the predictors of the formation of some JIA clinical variants were established:

- Rheumatoid factor positive polyarthritis (alleles/genotypes of the loci LTA rs909253 (only for the general group of boys and girls), MIF rs755622 (only for the general group of boys and girls));

- Rheumatoid factor negative polyarthritis (alleles/genotypes of the loci LTA rs909253 (for boys), IL2RA rs2104286 (for boys), IL10 rs1800872 (for boys) and the haplotype TNFA rs1800629*G LTA rs909253*G (for boys));

- Persistent oligoarthritis (alleles/genotypes of the loci LTA rs909253 (only for the general group of boys and girls), IL1B rs16944 (for boys), IL2-IL21 rs6822844 (for boys), IL6 rs1800795 (both for girls and for boys), IL10 rs1800872 (only for the general group of boys and girls), NFKB1 rs28362491 (only for the general group of boys and girls), PTPN22 rs2476601 (for girls) and the haplotype TNFA rs1800629*G - LTA rs909253*G (for girls));

- Extended oligoarthritis (alleles/genotypes of the loci IL2-IL21 rs6822844 (for girls), CTLA4 rs3087243 (for girls), PTPN22 rs2476601 (for girls));

- Enthesitis related arthritis (alleles/genotypes of the loci LTA rs909253 (for boys), IL6 rs1800795 (only for the general group of boys and girls), NFKB1 rs28362491 (for boys), PTPN22 rs2476601 (for boys) and the haplotype TNFA rs $1800629 * \mathrm{G}-$ LTA rs909253*G (for boys)); 
Table 2. The relationship between the immune response mediator genes polymorphic loci variants and the risk of the development of JIA and its clinical variants

\begin{tabular}{|c|c|c|}
\hline JIA and its clinical variants & The sex & The risk predictors \\
\hline \multirow{3}{*}{ JIA as a whole } & $\begin{array}{l}\text { the general group of } \\
\text { boys and girls }\end{array}$ & $\begin{array}{l}\left.\text { TNFA rs1800629*AA ( } \mathrm{p}=0.021, \mathrm{p}_{\mathrm{cor}}=0.020, \mathrm{OR}=0.112,95 \% \mathrm{Cl} 0.010-0.681\right) \text {, } \\
\text { PTPN22 } \mathrm{rs} 2476601 * \mathrm{GA}\left(\mathrm{p}=0.029, \mathrm{p}_{\mathrm{cor}}=0.029, \mathrm{OR}=1.551,95 \% \mathrm{Cl} 1.041-2.304\right), \\
\text { PTPN22 } \mathrm{rs} 2476601 * \mathrm{GG}\left(\mathrm{p}=0.035, \mathrm{p}_{\mathrm{cor}}=0.034, \mathrm{OR}=0.662,95 \% \mathrm{Cl} 0.450-0.960\right), \\
\text { haplotype TNFA rs1800629*G - LTA rs909253*G }(\mathrm{p}=0.016, \mathrm{OR}=1.41,95 \% \mathrm{Cl} 1.07-1.85)\end{array}$ \\
\hline & girls & $\begin{array}{l}\left.\text { TNFA rs1800629*AA ( } \mathrm{p}=0.031, \mathrm{p}_{\mathrm{cor}}=0.032, \mathrm{OR}=0.000,95 \% \mathrm{Cl} 0.000-0.757\right), \\
\left.\text { IL2-IL21 rs6822844*TT ( } \mathrm{p}=0.039, \mathrm{p}_{\mathrm{cor}}=0.037, \mathrm{OR}=0.132,95 \% \mathrm{Cl} 0.012-0.861\right) \\
\text { PTPN22 } \mathrm{rs} 2476601^{*} \mathrm{GG}\left(\mathrm{p}=0.039, \mathrm{p}_{\mathrm{cor}}=0.041, \mathrm{OR}=0.608,95 \% \mathrm{Cl} 0.391-0.952\right), \\
\text { PTPN22 } \mathrm{rs} 2476601^{*} \mathrm{~A}\left(\mathrm{p}=0.029, \mathrm{p}_{\mathrm{cor}}=0.031, \mathrm{OR}=1.583,95 \% \mathrm{Cl} 1.048-2.392\right)\end{array}$ \\
\hline & boys & $\begin{array}{l}\left.\text { LTA rs909253*AA ( } \mathrm{p}=0.043, \mathrm{p}_{\mathrm{cor}}=0.043, \mathrm{OR}=0.569,95 \% \mathrm{Cl} 0.334-0.991\right) \text {, } \\
\text { haplotype } T N F A \text { rs } 1800629^{*} \mathrm{G}-\angle T A \text { rs909253*G }(\mathrm{p}=0.018, \mathrm{OR}=1.79,95 \% \mathrm{Cl} 1.11-2.89)\end{array}$ \\
\hline $\begin{array}{l}\text { Rheumatoid factor } \\
\text { positive polyarthritis }\end{array}$ & $\begin{array}{l}\text { the general group of } \\
\text { boys and girls }\end{array}$ & $\begin{array}{l}\text { LTA rs909253*AG }\left(\mathrm{p}=0.007, \mathrm{p}_{\mathrm{cor}}=0.007, \mathrm{OR}=\mathrm{NA} \text { (NA }- \text { not available), } 95 \% \mathrm{Cl} 1.841-\mathrm{NA}\right), \\
\left.\text { LTA rs909253*AA ( } \mathrm{p}=0.030, \mathrm{p}_{\mathrm{cor}}=0.031, \mathrm{OR}=0.00,95 \% \mathrm{Cl} 0.00-0.745\right) \\
\text { MIF rs755622*C }\left(\mathrm{p}=0.031, \mathrm{p}_{\mathrm{cor}}=0.028, \mathrm{OR}=3.591,95 \% \mathrm{Cl} 1.119-11.472\right) \\
\text { MIF rs } 755622 * \mathrm{GG}\left(\mathrm{p}=0.042, \mathrm{p}_{\mathrm{cor}}=0.040, \mathrm{OR}=0.132,95 \% \mathrm{Cl} 0.011-0.975\right)\end{array}$ \\
\hline $\begin{array}{l}\text { Rheumatoid factor } \\
\text { negative polyarthritis }\end{array}$ & boys & 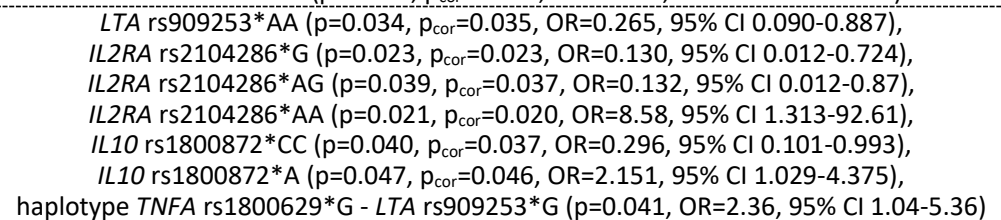 \\
\hline \multirow{3}{*}{ Persistent oligoarthritis } & $\begin{array}{l}\text { the general group of } \\
\text { boys and girls }\end{array}$ & 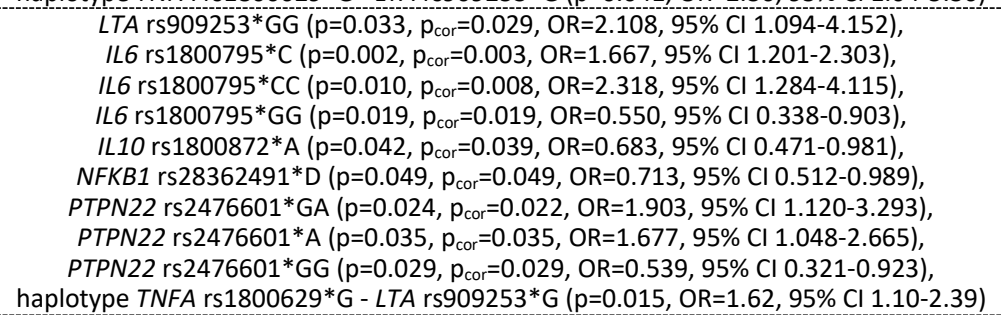 \\
\hline & girls & 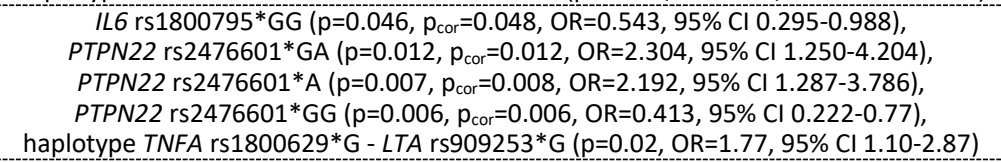 \\
\hline & boys & 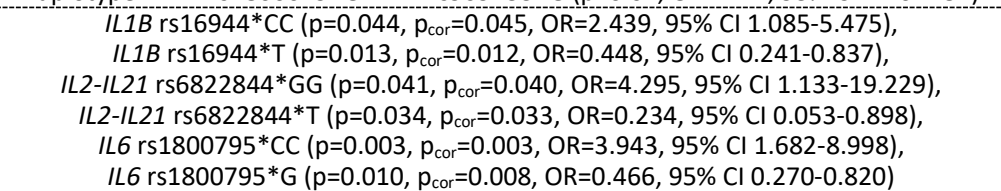 \\
\hline \multirow[b]{2}{*}{ Extended oligoarthritis } & $\begin{array}{l}\text { the general group of } \\
\text { boys and girls }\end{array}$ & $\begin{array}{l}\text { IL2-IL21 rs6822844*GG }\left(\mathrm{p}=0.048, \mathrm{p}_{\mathrm{cor}}=0.045, \mathrm{OR}=2.849,95 \% \mathrm{Cl} 1.032-7.623\right) \text {, } \\
\left.\text { IL2-IL21 rs6822844*T ( } \mathrm{p}=0.022, \mathrm{p}_{\mathrm{cor}}=0.021, \mathrm{OR}=0.329,95 \% \mathrm{Cl} 0.126-0.889\right) \\
\text { PTPN22 } \mathrm{rs} 2476601 * \mathrm{GA}\left(\mathrm{p}=0.035, \mathrm{p}_{\mathrm{cor}}=0.037, \mathrm{OR}=2.189,95 \% \mathrm{Cl} 1.085-4.482\right)\end{array}$ \\
\hline & girls & $\begin{array}{l}\text { IL2-IL21 rs6822844*T }\left(\mathrm{p}=0.021, \mathrm{p}_{\mathrm{cor}}=0.020, \mathrm{OR}=0.271,95 \% \mathrm{Cl} 0.087-0.841\right), \\
\text { CTLA4 rs3087243*GG }\left(\mathrm{p}=0.026, \mathrm{p}_{\mathrm{cor}}=0.026, \mathrm{OR}=2.171,95 \% \mathrm{Cl} 1.081-4.370\right), \\
\text { CTLA4 } \mathrm{rs} 3087243^{*} \mathrm{~A}\left(\mathrm{p}=0.044, \mathrm{p}_{\mathrm{cor}}=0.042, \mathrm{OR}=0.563,95 \% \mathrm{Cl} 0.321-0.971\right), \\
\text { PTPN22 } \mathrm{rs} 2476601^{*} \mathrm{GA}\left(\mathrm{p}=0.028, \mathrm{p}_{\mathrm{cor}}=0.029, \mathrm{OR}=2.407,95 \% \mathrm{Cl} 1.176-5.081\right)\end{array}$ \\
\hline \multirow[t]{2}{*}{ Enthesitis related arthritis } & $\begin{array}{l}\text { the general group of } \\
\text { boys and girls }\end{array}$ & $\begin{array}{l}\text { LTA rs909253*AG }\left(\mathrm{p}=0.002, \mathrm{p}_{\mathrm{cor}}=0.003, \mathrm{OR}=3.316,95 \% \mathrm{Cl} 1.564-6.769\right), \\
\text { LTA rs909253*G }\left(\mathrm{p}=0.041, \mathrm{p}_{\mathrm{cor}}=0.042, \mathrm{OR}=1.700,95 \% \mathrm{Cl} 1.041-2.758\right), \\
\text { LTA rs909253*AA }\left(\mathrm{p}=0.004, \mathrm{p}_{\mathrm{cor}}=0.003, \mathrm{OR}=0.307,95 \% \mathrm{Cl} 0.143-0.691\right), \\
\text { IL6 rs } 1800795^{*} \mathrm{CC}\left(\mathrm{p}=0.048, \mathrm{p}_{\mathrm{cor}}=0.0499, \mathrm{OR}=2.519,95 \% \mathrm{Cl} 1.115-5.867\right), \\
\text { PTPN22 rs } 2476601^{*} \mathrm{GA}\left(\mathrm{p}=0.029, \mathrm{p}_{\mathrm{cor}}=0.028, \mathrm{OR}=2.547,95 \% \mathrm{Cl} 1.122-5.608\right), \\
\text { PTPN22 rs2476601*A }\left(\mathrm{p}=0.022, \mathrm{p}_{\mathrm{cor}}=0.024, \mathrm{OR}=2.202,95 \% \mathrm{Cl} 1.128-4.170\right), \\
\text { PTPN22 rs } 2476601^{*} \mathrm{GG}\left(\mathrm{p}=0.021, \mathrm{p}_{\mathrm{cor}}=0.019, \mathrm{OR}=0.393,95 \% \mathrm{Cl} 0.183-0.833\right), \\
\text { haplotype TNFA rs1800629*G - LTA rs909253*G }(\mathrm{p}=0.0014, \mathrm{OR}=2.57,95 \% \mathrm{Cl} 1.44-4.56)\end{array}$ \\
\hline & boys & 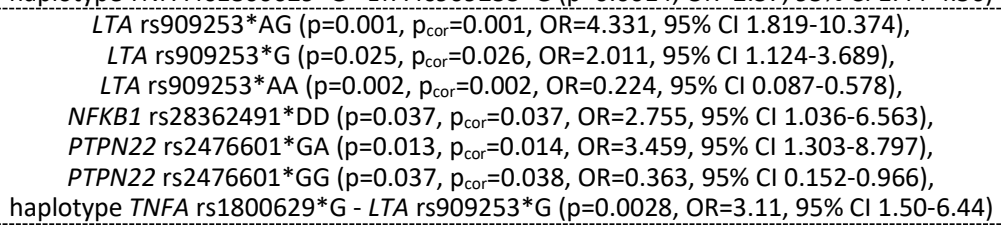 \\
\hline Psoriatic arthritis & $\begin{array}{l}\text { the general group of } \\
\text { boys and girls }\end{array}$ & haplotype TNFA rs1800629*G - LTA rs909253*G (p=0.039, OR=3.09, 95\% Cl 1.07-8.95) \\
\hline
\end{tabular}
boys and girls 
Table 3. Genetic predictors of the development of JIA and its clinical variants

\begin{tabular}{|c|c|c|c|c|c|c|c|c|c|c|c|c|c|c|}
\hline & & 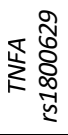 & 巨 & 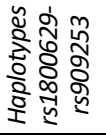 & 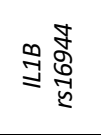 & 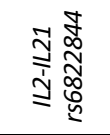 & 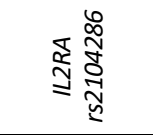 & 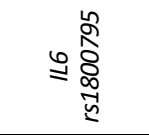 & 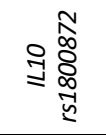 & 岕芯 & 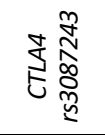 & 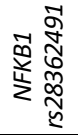 & 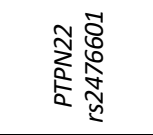 & 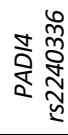 \\
\hline \multirow{3}{*}{ JIA } & $f+m$ & $A A$ & - & $\underline{\mathbf{G}-\mathbf{G}}$ & - & - & - & - & - & - & - & - & $\underline{\mathrm{GA}}, \mathrm{GG}$ & - \\
\hline & $f$ & $A A$ & - & - & - & $\pi$ & - & - & - & - & - & - & $\underline{A}, G, G G$ & - \\
\hline & $m$ & - & $A A$ & G-G & - & - & - & - & - & - & - & - & - & - \\
\hline \multicolumn{15}{|c|}{ Clinical variants of JIA } \\
\hline Systemic arthritis & $\begin{array}{c}f+m, f, \\
m\end{array}$ & - & - & - & - & - & - & - & - & - & - & - & - & - \\
\hline $\begin{array}{l}\text { Rheumatoid factor } \\
\text { positive polyarthritis }\end{array}$ & $f+m$ & - & $\underline{\mathrm{AG}}, A A$ & - & - & - & - & - & - & $\underline{\mathbf{C}}, G, G G$ & - & - & - & - \\
\hline \multirow{3}{*}{$\begin{array}{l}\text { Rheumatoid factor } \\
\text { negative polyarthritis }\end{array}$} & $\mathrm{f}+\mathrm{m}$ & - & - & - & - & - & - & - & - & - & - & - & - & - \\
\hline & $\mathrm{f}$ & - & - & - & - & - & - & - & - & - & - & - & - & - \\
\hline & $m$ & - & $A A$ & G-G & - & - & $\mathrm{AA}, \mathrm{A}, A G, G$ & - & A, C, CC & - & - & - & - & - \\
\hline \multirow{3}{*}{ Persistent oligoarthritis } & $\mathrm{f}+\mathrm{m}$ & - & GG & G-G & - & - & - & CC, C, GG, G & C, $A$ & - & - & I, $D$ & $\mathrm{GA}, \mathrm{A}, G G, G$ & - \\
\hline & $f$ & - & - & $\underline{\mathbf{G}-\mathbf{G}}$ & - & - & - & GG & - & - & - & - & $\underline{\mathbf{G A}}, \mathbf{A}, G G, G$ & - \\
\hline & $\mathrm{m}$ & - & - & - & $\mathrm{CC}, \mathrm{C}, T$ & $\mathbf{G G}, \mathbf{G}, T$ & - & $\mathrm{CC}, \mathrm{C}, \mathrm{G}$ & - & - & - & - & - & - \\
\hline \multirow{3}{*}{ Extended oligoarthritis } & $\mathrm{f}+\mathrm{m}$ & - & - & - & - & $\underline{\mathbf{G G}, \mathbf{G}}, T$ & - & - & - & - & - & - & GA & - \\
\hline & $f$ & - & - & - & - & $\underline{\mathbf{G}}, T$ & - & - & - & - & $\underline{\mathbf{G G}, \mathbf{G}}, A$ & - & $\underline{\mathbf{G A}}$ & - \\
\hline & $m$ & - & - & - & - & - & - & - & - & - & - & - & - & - \\
\hline \multirow{3}{*}{$\begin{array}{c}\text { Enthesitis related } \\
\text { arthritis }\end{array}$} & $f+m$ & - & $\mathrm{AG}, \mathrm{G}, A A, A$ & $\underline{\mathbf{G}-\mathbf{G}}$ & - & - & - & $\underline{C C}$ & - & - & - & - & $\mathrm{GA}, \mathbf{A}, G G, G$ & - \\
\hline & $f$ & - & - & - & - & - & - & - & - & - & - & - & - & - \\
\hline & $m$ & -1 & AG, $\mathbf{G}, A A, A$ & G-G & - & - & - & - & - & - & - & DD & GA, GG & - \\
\hline Psoriatic arthritis & $\mathrm{f}+\mathrm{m}$ & - & - & $\mathbf{G - G}$ & - & - & - & - & - & - & - & - & - & - \\
\hline
\end{tabular}

Hereinafter in the tables: $f+m$, female and male; $f$, female; $m$, male; alleles, genotypes and haplotypes for which $O R>1$ ( $<<0.05$ ) are highlighted in bold underlined font on a gray background; alleles, genotypes and haplotypes for which $\mathrm{OR}<1(\mathrm{p}<0.05)$ are italicized.

- Psoriatic arthritis (the haplotype TNFA rs $1800629 * G$ - LTA rs909253*G (only for the general group of boys and girls)).

It should be noted that the Rheumatoid factor positive polyarthritis and Psoriatic arthritis patients samples were small, which is why the sex stratification was not carried out.Associations with the development of the Systemic arthritis for the studied polymorphic variants of the immune response mediator genes were not detected, including in the sex-stratified analysis ( $p>0.05)$.

\section{Discussion}

As a result of this work, the relationship of the alleles, genotypes and haplotypes of a number of the immune response mediator genes polymorphic loci with the risk of the development of JIA and its clinical variants - Rheumatoid factor positive polyarthritis, Rheumatoid factor negative polyarthritis (only in boys), Persistent oligoarthritis, Extended oligoarthritis, Enthesitis related arthritis, Psoriatic arthritis - was established. Specific associations were observed for girls and boys, which indicates the existence of sexual dimorphism in the JIA pathogenesis. For girls, the risk markers of JIA in general, as well as of Persistent oligoarthritis and Extended oligoarthritis were established, and for boys - of JIA in general and of Rheumatoid factor negative polyarthritis, Persistent oligoarthritis, Enthesitis related arthritis (Table 3).

Some of the examined polymorphic variants of the immune response mediator genes have previously been studied for a relationship with the JIA development in separate ethnic groups, but the results are contradictory. Nevertheless, the data of a number of papers are generally consistent with the results of the present study. The protective effect on the development of JIA and/or its clinical variants was shown for the TNFA rs1800629*A allele in the work of Schmeling $\mathrm{H}$. et al. (2006), Kaalla M.J. et al. (2013), Reinards T.H. et al. (2015); for the IL2-IL21 rs6822844*T allele - in the works of Albers H.M. et al. (2009), Hinks A. et al. (2010); for the IL2RA rs $2104286^{*} \mathrm{G}$ allele - in the works of Hinks A. et al. (2009), Thompson S.D. et al. (2010) [12-18]. According to Crawley E. et al. (1999), the presence of ATA-containing genotypes of the IL10 gene rs1800896, rs1800871 and rs1800872 polymorphic loci haplotypes was significantly more characteristic for patients with Extended oligoarthritis, than for those with Persistent oligoarthritis [19]. A number of authors have shown that the PTPN22 rs2476601*A allele marks an increased risk of the development of JIA in general and of some of its variants $[2,13$, 18, 20-22]. According to the latest data, the association of the PTPN22 rs2476601*A allele with the JIA development is characteristic only for girls [23].

At the same time, according to a number of studies, the TNFA rs1800629*A allele marks an increased risk of the development of JIA in general (in the Mexican population) or its polyarticular (in the Serbian population) and oligoarticular (in the British population) variants [24-26]. Several studies have reported the absence of a relationship between the TNFA rs1800629 polymorphic locus variants and the risk of the JIA development in the Portuguese, Spanish, Turkish, Czech, German, French and Italian populations [27-32]. A replicative study of Ellis et al. (2013) did not reveal the relationship of the IL2-IL21 rs6822844 polymorphic locus alleles with the JIA development in the Australian population [33]. Prahalad et al. (2009) and Reinards et al. (2015) reported the absence of a relationship of the IL2RA rs2104286 polymorphic locus alleles with the development of JIA or its variants in children of European descent, and Ellis et al. (2013) - with the development of JIA in the Australian population $[14,33,34]$. Oen et al. (2005) also reported the absence of associations of the IL10 rs1800896, rs1800871 and rs1800872 polymorphic loci genotypes and the genotypes of their haplotypes with the development of JIA and its variants in children of European descent [35]. In the Chinese and Hungarian populations, no relationship was found between the PTPN22 rs2476601 polymorphic locus variants and the development of JIA, however, the sample size in these studies was relatively small [36, 37]. 
When analyzing the MIF rs755622 polymorphic locus, Donn et al. (2002) found that the MIF rs $755622^{*} \mathrm{C}$ allele marks an increased risk of the JIA development in children from the UK [38]. Several studies (on samples of European origin (from the USA and Germany), as well as in the Turkish population) have reported on the absence of a relationship of the MIF rs755622 polymorphic locus alleles and genotypes with the development of JIA and / or its variants $[13,27,39]$. At the same time, Reinards et al. (2015) found that the MIF rs $755622^{*} \mathrm{C}$ allele marks a protective effect on the JIA development in children of European descent [14].

The CTLA4 rs3087243 polymorphic locus has been studied in JIA by several authors groups. Suppiah et al. (2006), Prahalad et al. (2008) and Ellis et al. (2013) did not reveal any independent associations of the CTLA4 rs3087243 polymorphic locus variants (in isolated analysis, excluding haplotypes) with the JIA development in individuals from Northern Ireland, the USA (predominantly of Northern European ancestry) and Australia, respectively [33, 40, 41]. However, Hinks et al. (2010) on a sample of European origin from the UK, as well as in a meta-analysis with the inclusion of the Prahalad et al. (2008) data showed a borderline significance level $(p=0.05)$ for the rarer occurrence of the CTLA4 rs3087243*A allele in JIA patients than in controls [16]

The observed inconsistency of the results is probably related to the samples characteristics (including sample size, ethnic factors), the pronounced clinical heterogeneity of JIA and the presence of sexual dimorphism in the disease pathogenesis, which indicates the need to consider these aspects when studying the molecular genetic basis of JIA

\section{Conclusion}

In this work, the relationship of the alleles, genotypes and haplotypes of a number of the immune response mediator genes polymorphic loci with the risk of the development of JIA and its clinical variants was established. Specific associations were observed for girls and boys, which indicates the existence of sexual dimorphism in the JIA pathogenesis.

\section{Funding}

The work was supported by:

i) Government project: "Study of molecular genetic mechanisms of formation of multifactorial pathology", No. 115060810015 (08 June 2015).

ii) Grant of the Republic of Bashkortostan to young scientists and youth scientific teams, contract No. 6 (25 March 2016).

iii) The program "Participant of the Youth Scientific and Innovation Contest" ("UMNIK"), contracts No. 10/16859 (28 May 2012) and No. 10/20810 (01 July 2013).

\section{Conflict of interest}

The authors declare that they have no conflict of interest.

\section{Ethical approval}

All procedures performed in studies involving human participants were in accordance with the standards of the Local ethical committee of Bashkir State Medical University (Ufa, Russia) and with the 1964 Helsinki declaration and its later amendments or comparable ethical standards.

\section{References}

1. Ravelli A, Martini A. Juvenile idiopathic arthritis. Lancet 2007; 369(9563): 767-778. https://doi.org/10.1016/S0140-6736(07)60363-8.
2. Hersh AO, Prahalad S. Immunogenetics of juvenile idiopathic arthritis: A comprehensive review. J Autoimmun 2015; 64: 113-124. https://doi.org/10.1016/j.jaut.2015.08.002

3. Cobb JE, Hinks A, Thomson W. The genetics of juvenile idiopathic arthritis: current understanding and future prospects. Rheumatology (Oxford) 2014; 53(4): 592-599. https://doi.org/10.1093/rheumatology/ket314.

4. Prahalad S, Glass DN. A comprehensive review of the genetics of juvenile idiopathic arthritis. Pediatr Rheumatol Online J 2008; 6: 11 https://dx.doi.org/10.1186/1546-0096-6-11.

5. Petty RE, Southwood TR, Manners P, Baum J, Glass DN, Goldenberg J, et al. International League of Associations for Rheumatology classification of juvenile idiopathic arthritis: second revision, Edmonton, 2001. J Rheumatol 2004; 31(2): 390-392. https://www.ncbi.nlm.nih.gov/pubmed/14760812.

6. Mathew CG. The isolation of high molecular weight eukaryotic DNA. Methods Mol Biol 1985; 2: 31-34. https://doi.org/10.1385/0-89603064-4:31.

7. Liu K, Muse SV. PowerMarker: an integrated analysis environment for genetic marker analysis. Bioinformatics 2005; 21(9): 2128-2129. https://doi.org/10.1093/bioinformatics/bti282.

8. R Core Team; R Foundation for Statistical Computing. R: A Language and Environment for Statistical Computing. Vienna, Austria, 2017. https://www.R-project.org.

9. Solé X, Guinó E, Valls J, Iniesta R, Moreno V. SNPStats: a web tool for the analysis of association studies. Bioinformatics 2006; 22(15): 19281929. https://doi.org/10.1093/bioinformatics/btl268.

10. Westfall PH, Young SS. Resampling-Based Multiple Testing: Examples and Methods for p-Value Adjustment. New York, USA: Wiley, 1993, $360 \mathrm{p}$.

11. Fagerland MW, Lydersen S, Laake P. Recommended confidence intervals for two independent binomial proportions. Stat Methods Med Res 2015; 24(2): 224-254 https://doi.org/10.1177/0962280211415469.

12. Schmeling $H$, Wagner $U$, Peterson A, Horneff $G$. Tumor necrosis factor alpha promoter polymorphisms in patients with juvenile idiopathic arthritis. Clin Exp Rheumatol 2006; 24(1): 103-108. https://www.ncbi.nlm.nih.gov/pubmed/16539828.

13. Kaalla MJ, Broadaway KA, Rohani-Pichavant M, Conneely KN, Whiting $A$, Ponder $L$, et al. Meta-analysis confirms association between TNFAG238A variant and JIA, and between PTPN22-C1858T variant and oligoarticular, RF-polyarticular and RF-positive polyarticular JIA. Pediatr Rheumatol Online J 2013; 11(1): 40. https://doi.org/10.1186/1546-0096-11-40.

14. Reinards TH, Albers HM, Brinkman DM, Kamphuis SS, van Rossum MA, Girschick HJ, et al. CD226 (DNAM-1) is associated with susceptibility to juvenile idiopathic arthritis. Ann Rheum Dis 2015; 74(12): 2193-2198. http://doi.org/10.1136/annrheumdis-2013-205138.

15. Albers HM, Kurreeman FA, Stoeken-Rijsbergen G, Brinkman DM, Kamphuis SS, van Rossum MA, et al. Association of the autoimmunity locus 4q27 with juvenile idiopathic arthritis. Arthritis Rheum 2009; 60(3): 901-904. https://doi.org/10.1002/art.24296.

16. Hinks A, Eyre S, Ke X, Barton A, Martin P, Flynn E, et al. Association of the AFF3 gene and IL2/IL21 gene region with juvenile idiopathic arthritis. Genes Immun 2010; 11(2): 194-198. https://doi.org/10.1038/gene.2009.105.

17. Hinks A, Ke X, Barton A, Eyre S, Bowes J, Worthington J, et al. Association of the IL2RA/CD25 gene with juvenile idiopathic arthritis. Arthritis Rheum 2009; 60(1): 251-257. https://doi.org/10.1002/art.24187.

18. Thompson SD, Sudman M, Ramos PS, Marion MC, Ryan M, Tsoras M, et al. The susceptibility loci juvenile idiopathic arthritis shares with other autoimmune diseases extend to PTPN2, COG6, and ANGPT1. Arthritis Rheum 2010; 62(11): 3265-3276. https://doi.org/10.1002/art.27688. 
19. Crawley E, Kay R, Sillibourne J, Patel P, Hutchinson I, Woo P. Polymorphic haplotypes of the interleukin-10 5' flanking region determine variable interleukin-10 transcription and are associated with particular phenotypes of juvenile rheumatoid arthritis. Arthritis Rheum 1999; 42(6): 1101-1108. https://doi.org/10.1002/15290131(199906)42:6<1101::AID-ANR6>3.0.CO;2-Y.

20. Viken MK, Amundsen SS, Kvien TK, Boberg KM, Gilboe IM, Lilleby V, et al. Association analysis of the $1858 \mathrm{C}>\mathrm{T}$ polymorphism in the PTPN22 gene in juvenile idiopathic arthritis and other autoimmune diseases. Genes Immun 2005; 6(3): 271-273. https://doi.org/10.1038/sj.gene.6364178.

21. Hinks A, Barton A, John S, Bruce I, Hawkins C, Griffiths CE, et al. Association between the PTPN22 gene and rheumatoid arthritis and juvenile idiopathic arthritis in a UK population: further support that PTPN22 is an autoimmunity gene. Arthritis Rheum 2005; 52(6): 16941699. https://doi.org/10.1002/art.21049.

22. Lee $\mathrm{YH}, \mathrm{Bae} \mathrm{SC}$, Song GG. The association between the functional PTPN22 $1858 \mathrm{C} / \mathrm{T}$ and MIF -173 C/G polymorphisms and juvenile idiopathic arthritis: a meta-analysis. Inflamm Res 2012; 61(5): 411-415. https://doi.org/10.1007/s00011-012-0447-5.

23. Goulielmos GN, Chiaroni-Clarke RC, Dimopoulou DG, Zervou MI, Trachana M, Pratsidou-Gertsi P, et al. Association of juvenile idiopathic arthritis with PTPN22 rs2476601 is specific to females in a Greek population. Pediatr Rheumatol Online J 2016; 14(1): 25. https://doi.org/10.1186/s12969-016-0087-3.

24. Basic J, Pavlovic D, Jevtovic-Stoimenov T, Vojinovic J, Susic G, Stojanovic I, et al. Etanercept reduces matrix metalloproteinase-9 level in children with polyarticular juvenile idiopathic arthritis and TNFalpha-308GG genotype. J Physiol Biochem 2010; 66(2): 173-180. https://doi.org/10.1007/s13105-010-0022-x.

25. Zeggini E, Thomson W, Kwiatkowski D, Richardson A, Ollier W, Donn R, et al. Linkage and association studies of single-nucleotide polymorphism-tagged tumor necrosis factor haplotypes in juvenile oligoarthritis. Arthritis Rheum 2002; 46(12): 3304-3311. https://doi.org/10.1002/art.10698.

26. Jiménez-Morales $\mathrm{S}$, Velázquez-Cruz R, Ramírez-Bello J, BonillaGonzález E, Romero-Hidalgo S, Escamilla-Guerrero G, et al. Tumor necrosis factor-alpha is a common genetic risk factor for asthma, juvenile rheumatoid arthritis, and systemic lupus erythematosus in a Mexican pediatric population. Hum Immunol 2009; 70(4): 251-256. https://doi.org/10.1016/j.humimm.2009.01.027.

27. Miterski B, Drynda S, Böschow G, Klein W, Oppermann J, Kekow J, et al. Complex genetic predisposition in adult and juvenile rheumatoid arthritis. BMC Genet 2004; 5: 2. https://doi.org/10.1186/1471-2156-5-2.

28. Cimaz R, Cazalis MA, Reynaud C, Gerloni V, Zulian F, Biggioggero M, et al. IL1 and TNF gene polymorphisms in patients with juvenile idiopathic arthritis treated with TNF inhibitors. Ann Rheum Dis 2007; 66(7): 900904. http://doi.org/10.1136/ard.2006.067454.

29. Scardapane A, Breda L, Lucantoni M, Chiarelli F. TNF- $\alpha$ Polymorphisms in Juvenile Idiopathic Arthritis: Which Potential Clinical Implications? Int J Rheumatol 2012; 2012: 756291. http://doi.org/10.1155/2012/756291.

30. Modesto C, Patiño-García A, Sotillo-Piñeiro E, Merino J, GarcíaConsuegra J, Merino R, et al. TNF-alpha promoter gene polymorphisms in Spanish children with persistent oligoarticular and systemic-onset juvenile idiopathic arthritis. Scand J Rheumatol 2005; 34(6): 451-454. https://doi.org/10.1080/03009740510026652.

31. Mourão AF, Caetano-Lopes J, Costa $P$, Canhão H, Santos MJ, Pinto $P$, et al. Tumor necrosis factor-alpha -308 genotypes influence inflammatory activity and TNF-alpha serum concentrations in children with juvenile idiopathic arthritis. J Rheumatol 2009; 36(4): 837-842. https://doi.org/10.3899/jrheum.080615.

32. Ozen S, Alikasifoglu M, Bakkaloglu A, Duzova A, Jarosova K, Nemcova D, et al. Tumour necrosis factor alpha G-->A -238 and G-->A -308 polymorphisms in juvenile idiopathic arthritis. Rheumatology (Oxford) 2002; 41(2): 223-227. https://doi.org/10.1093/rheumatology/41.2.223.
33. Ellis JA, Chavez RA, Pezic A, Ponsonby AL, Akikusa JD, Allen RC, et al. Independent replication analysis of genetic loci with previous evidence of association with juvenile idiopathic arthritis. Pediatr Rheumatol Online J 2013; 11(1): 12. https://doi.org/10.1186/1546-0096-11-12

34. Prahalad S, Hansen S, Whiting A, Guthery SL, Clifford B, McNally B, et al. Variants in TNFAIP3, STAT4, and C12orf30 loci associated with multiple autoimmune diseases are also associated with juvenile idiopathic arthritis. Arthritis Rheum 2009; 60(7): 2124-2130. https://doi.org/10.1002/art.24618.

35. Oen K, Malleson PN, Cabral DA, Rosenberg AM, Petty RE, Nickerson P, et al. Cytokine genotypes correlate with pain and radiologically defined joint damage in patients with juvenile rheumatoid arthritis. Rheumatology (Oxford) 2005; 44(9): 1115-1121. https://doi.org/10.1093/rheumatology/keh689.

36. Pazár B, Gergely P Jr, Nagy ZB, Gombos T, Pozsonyi E, Rajczy K, et al. Role of HLA-DRB1 and PTPN22 genes in susceptibility to juvenile idiopathic arthritis in Hungarian patients. Clin Exp Rheumatol 2008 26(6): 1146-1152. https://www.ncbi.nlm.nih.gov/pubmed/19210888.

37. Fan ZD, Wang FF, Huang $\mathrm{H}$, Huang $\mathrm{N}, \mathrm{Ma} \mathrm{HH}$, Guo $\mathrm{YH}$, et al. STAT4 rs7574865 G/T and PTPN22 rs2488457 G/C polymorphisms influence the risk of developing juvenile idiopathic arthritis in Han Chinese patients. PLoS One 2015; 10(3): e0117389. https://doi.org/10.1371/journal.pone.0117389.

38. Donn R, Alourfi Z, De Benedetti F, Meazza C, Zeggini E, Lunt M, et al. Mutation screening of the macrophage migration inhibitory factor gene: positive association of a functional polymorphism of macrophage migration inhibitory factor with juvenile idiopathic arthritis. Arthritis Rheum 2002; 46(9): 2402-2409. https://doi.org/10.1002/art.10492.

39. Berdeli A, Ozyürek AR, Ulger Z, Gürses D, Levent E, Salar K, et al. Association of macrophage migration inhibitory factor gene $-173 \mathrm{G} / \mathrm{C}$ polymorphism with prognosis in Turkish children with juvenile rheumatoid arthritis. Rheumatol Int 2006; 26(8): 726-731. https://doi.org/10.1007/s00296-005-0062-7.

40. Prahalad S, Bohnsack JF, Whiting A, Clifford B, Jorde LB, Guthery SL, et al. Lack of association of functional CTLA4 polymorphisms with juvenile idiopathic arthritis. Arthritis Rheum 2008; 58(7): 2147-2152. https://doi.org/10.1002/art.23602.

41. Suppiah V, O'Doherty C, Heggarty S, Patterson CC, Rooney M, Vandenbroeck K. The CTLA4+49A/G and CT60 polymorphisms and chronic inflammatory arthropathies in Northern Ireland. Exp Mol Pathol 2006; 80(2): 141-146. https://doi.org/10.1016/j.yexmp.2005.09.004.

\section{Authors:}

Liliia Sh. Nazarova - MD, PhD, Assistant, Department of Therapy and Occupational Diseases with the course of Institute of Additional Professional Education, Bashkir State Medical University, Ufa, Russia. http://orcid.org/0000-0002-9666-5650.

Ksenia V. Danilko - PhD, Associate Professor, Associate Professor of the Department of Biology, Senior Researcher of the Central Research Laboratory, Bashkir State Medical University, Ufa, Russia. http://orcid.org/0000-0002-4374-2923.

Viktor A. Malievsky - MD, DSc, Professor, Head of the Department of Hospital Pediatrics, Bashkir State Medical University, Ufa, Russia. http://orcid.org/0000-0003-0522-7442.

Akhat B. Bakirov - MD, DSc, Professor, Academician of Academy of Sciences of the Republic of Bashkortostan, Head of the Department of Therapy and Occupational Diseases with the course of Institute of Additional Professional Education, Bashkir State Medical University; Director, Ufa Research Institute of Occupational Health and Human Ecology, Ufa, Russia. http://orcid.org/0000-0003-3510-2595.

Tatiana V. Viktorova - MD, DSc, Professor, Head of the Department of Biology, Bashkir State Medical University; Chief Researcher, Laboratory of Physiological Genetics, Institute of Biochemistry and Genetics, Ufa, Russia. http://orcid.org/0000-0001-8900-2480. 


\begin{tabular}{|c|c|c|c|c|c|c|c|c|c|c|}
\hline \multicolumn{3}{|c|}{ Polymorphic locus } & \multirow[t]{3}{*}{ Subjects } & \multirow{2}{*}{\multicolumn{2}{|c|}{$\begin{array}{c}\text { The whole group }(f+m) \\
\text { Alleles and genotypes } \\
\text { frequencies, } \%\end{array}$}} & \multirow{2}{*}{\multicolumn{2}{|c|}{$\begin{array}{c}\text { Female }(f) \\
\text { Alleles and genotypes } \\
\text { frequencies, \% }\end{array}$}} & \multirow{2}{*}{\multicolumn{2}{|c|}{$\begin{array}{c}\text { Male }(m) \\
\text { Alleles and genotypes } \\
\text { frequencies, \% }\end{array}$}} & \multirow{3}{*}{$\begin{array}{l}n_{i} \\
\text { The total number of } \\
\text { genotyped subjects, } n_{i} \\
f+m: f: m\end{array}$} \\
\hline \multirow[t]{2}{*}{ Gene } & \multirow[t]{2}{*}{ rs } & \multirow{2}{*}{$\begin{array}{c}\text { Alleles } \\
(1) /(2)\end{array}$} & & & & & & & & \\
\hline & & & & (2) & $(11) /(12) /(22)$ & (2) & $(11) /(12) /(22)$ & $(2)$ & $(11) /(12) /(22)$ & \\
\hline \multirow[b]{2}{*}{ TNFA } & \multirow[b]{2}{*}{1800629} & \multirow[b]{2}{*}{$\mathrm{G} / \mathrm{A}$} & pat & 10.2 & $80.0 / 19.7 / 0.3$ & & $79.3 / 20.7 / 0.0$ & 9.7 & $81.4 / 17.7 / 0.9$ & $330: 217: 113$ \\
\hline & & & contr & 13.2 & $1 / 2.6$ & & $73.7 / 23.7 / 2.5$ & 10.4 & $82.1 / 15.1 / 2.8$ & $342: 236: 106$ \\
\hline \multirow{2}{*}{ LTA } & \multirow{2}{*}{909253} & \multirow[b]{2}{*}{$A / G$} & patients & 32.4 & $45.8 / 43.6 / 10.6$ & 30.4 & $48.8 / 41.5 / 9.7$ & 36.3 & $39.8 / 47.8 / 12.4$ & $330: 217: 113$ \\
\hline & & & cont & $\overline{29.4}$ & $0 / 7.9$ & $\overline{30.3}$ & $45.3 / 7.6$ & $\overline{27.4}$ & $53.8 / 37.7 / 8.5$ & $\overline{342: 236: 106}$ \\
\hline \multirow{2}{*}{ IL1B } & \multirow{2}{*}{16944} & \multirow{2}{*}{$C / T$} & patients & 36.2 & $41.2 / 45.2 / 13.6$ & 37.3 & $37.8 / 49.8 / 12.4$ & 34.1 & $47.8 / 36.3 / 15.9$ & $330: 217: 113$ \\
\hline & & & contr & $\overline{37.9}$ & $\overline{38.9 / 46.5 / 14.6}$ & $\overline{37.1}$ & $\overline{39.0 / 47.9 / 13.1}$ & $\overline{39.6}$ & $\overline{38.7 / 43.4 / 17.9}$ & $\overline{342: 236: 106}$ \\
\hline \multirow{2}{*}{ IL2-21 } & \multirow{2}{*}{6822844} & \multirow{2}{*}{$\mathrm{G} / \mathrm{T}$} & patients & 9.4 & $.0 / 0.9$ & 10.1 & 80. & 8.0 & $85.8 / 12.4 / 1.8$ & $330: 217: 113$ \\
\hline & & & controls & $\overline{12.1}$ & $4 / 2.9$ & 12 & $\overline{78.8}$ & $\overline{11.8}$ & $\overline{78.3 / 19.8 / 1.9}$ & $\overline{342: 236: 106}$ \\
\hline \multirow[b]{2}{*}{ IL2RA } & \multirow{2}{*}{2104286} & \multirow[b]{2}{*}{$A / G$} & patients & 17.0 & $69.1 / 2$ & 18 & & 14.2 & 73 & $330: 217: 113$ \\
\hline & & & controls & 17.4 & 68.4 & 16 & 69 & 18 & 65 & $342: 236: 106$ \\
\hline \multirow[b]{2}{*}{ IL6 } & \multirow{2}{*}{1800795} & \multirow[b]{2}{*}{$\mathrm{G} / \mathrm{C}$} & patients & 38.5 & $37.6 /$ & 38 & 35. & 39.4 & $42.5 /$ & $330: 217: 113$ \\
\hline & & & & 34.2 & & & & & & $342: 236: 106$ \\
\hline \multirow{2}{*}{ IL10 } & \multirow{2}{*}{1800872} & \multirow{2}{*}{ C/A } & patients & 29.8 & 50. & 27 & $\underline{52}$ & 34.1 & $46.0 / 39.8 / 14.2$ & $330: 217: 113$ \\
\hline & & & controls & $\overline{31.6}$ & $47.7 / 41.5 / 10.8$ & $\overline{32.6}$ & $\overline{46.2 / 42.4 / 11.4}$ & $\overline{29.2}$ & $\overline{50.9 / 39.6 / 9.4}$ & $\overline{342: 236: 106}$ \\
\hline MME & & & patients & $\underline{19.1}$ & $65.5 / 30.9 / 3.6$ & $\underline{18.7}$ & $65.4 / 31.8 / 2.8$ & 19.9 & $65.5 / 29.2 / 5.3$ & $330: 217: 113$ \\
\hline MIIr & 755622 & $\mathrm{G} / \mathrm{C}$ & controls & $\overline{21.8}$ & $60.2 / 36.0 / 3.8$ & 22 & $\frac{59.7 / 36.0 / 4.2}{59.2}$ & 20 & $\frac{0.1 .3 / 35.8 / 2.8}{61.8}$ & $342: 236: 106$ \\
\hline & & & patients & 32.0 & $47.9 / 40.3 / 11.8$ & 32.3 & $47.0 / 41.5 / 11.5$ & 31.4 & $49.6 / 38.1 / 12.4$ & $330: 217: 113$ \\
\hline & & & trols & $\overline{34.6}$ & $42.7 / 45.3 / 12.0$ & 36 & $39.4 / 48.3 / 12.3$ & 30.7 & $50.0 / 38.7 / 11.3$ & $342: 236: 106$ \\
\hline & & & patients & $\underline{43.0}$ & $32.7 / 48.5 / 18.8$ & & $31.3 / 50.7 / 18.0$ & $\underline{42.5}$ & $35.4 / 44.2 / 20.4$ & $330: 217: 113$ \\
\hline N & 2 & I/D & controls & $\overline{44.9}$ & $31.0 / 48.2 / 20.8$ & $\frac{47.2}{47.2}$ & $28.4 / 48.7 / 22.9$ & $\overline{39.6}$ & $\overline{36.8 / 47.2 / 16.0}$ & $\overline{342: 236: 106}$ \\
\hline בTPN2 & 2476601 & $G / A$ & patients & $\underline{12.7}$ & $76.4 / 21.8 / 1.8$ & $\underline{14.1}$ & $74.2 / 23.5 / 2.3$ & 10.2 & $80.5 / 18.6 / 0.9$ & $330: 217: 113$ \\
\hline PIPINZL & $24 / 6601$ & G/A & & $\overline{9.4}$ & & 9 & & 9.4 & & $341: 235: 106$ \\
\hline & 6 & & patients & 42.9 & $32.1 / 50.0 / 17.9$ & 42.9 & $\underline{32.7 / 48.8 / 18.4}$ & $\underline{42.9}$ & $31.0 / 52.2 / 16.8$ & $330: 217: 113$ \\
\hline$P J$ & 6 & G/A & controls & $\overline{43.1}$ & $\overline{32.3 / 49.3 / 18.5}$ & $\overline{43.2}$ & $\overline{32.6 / 48.3 / 19.1}$ & $\overline{42.9}$ & $\overline{31.4 / 51.4 / 17.1}$ & $\overline{341: 236: 105}$ \\
\hline
\end{tabular}

Hereinafter: (1), the major allele; (2), the minor allele; (11) and (22), genotypes homozygous for the major and minor alleles, respectively; (12), heterozygous genotype; $f+m$, female and male; $f$, female; $m$, male.

Supplementary Table 2. Analysis of the distribution of the polymorphic loci alleles and genotypes in patients with Rheumatoid factor negative polyarthritis and in the control group

\begin{tabular}{|c|c|c|c|c|c|c|c|c|c|c|}
\hline \multicolumn{3}{|c|}{ Polymorphic locus } & \multirow[t]{3}{*}{ Subjects } & \multirow{2}{*}{\multicolumn{2}{|c|}{$\begin{array}{l}\text { The whole group }(f+m) \\
\text { Alleles and genotypes } \\
\text { frequencies, } \%\end{array}$}} & \multirow{2}{*}{\multicolumn{2}{|c|}{$\begin{array}{c}\text { Female }(f) \\
\text { Alleles and genotypes } \\
\text { frequencies, } \%\end{array}$}} & \multicolumn{2}{|r|}{ Male $(m)$} & \multirow{2}{*}{$\begin{array}{l}n_{i} \\
\text { The total number of } \\
\text { genotyped subjects, } n_{i}\end{array}$} \\
\hline \multirow[t]{2}{*}{ Gene } & \multirow[t]{2}{*}{ rs } & \multirow{2}{*}{$\begin{array}{l}\text { Alleles } \\
(1) /(2)\end{array}$} & & & & & & Allel & $\begin{array}{l}\text { and genotypes } \\
\text { quencies, } \%\end{array}$ & \\
\hline & & & & $(2)$ & $(11) /(12) /(22)$ & (2) & $(11) /(12) /(22)$ & $(2)$ & $(11) /(12) /(22)$ & $f+m: f: m$ \\
\hline \multirow{2}{*}{ TNFA } & \multirow{2}{*}{1800629} & \multirow{2}{*}{$\mathrm{G} / \mathrm{A}$} & $\underline{\mathrm{ts}}$ & $\underline{11.0}$ & 77.9/22.1/0.0 & $\underline{10.9}$ & 78.3/21.7/0.0 & 11.8 & $76.5 / 23.5 / 0.0$ & $86: 69: 17$ \\
\hline & & & controls & 13.2 & $76.3 / 21.1 / 2.6$ & 14.4 & $73.7 / 23.7 / 2.5$ & 10.4 & $82.1 / 15.1 / 2.8$ & $342: 236: 106$ \\
\hline \multirow{2}{*}{ LTA } & \multirow{2}{*}{909253} & \multirow{2}{*}{$A / G$} & patients & 27.3 & $53.5 / 38.4 / 8.1$ & 23.2 & $60.9 / 31.9 / 7.2$ & 44.1 & $23.5 / 64.7 / 11.8$ & $86: 69: 17$ \\
\hline & & & controls & $\overline{29.4}$ & $49.1 / 43.0 / 7.9$ & $\overline{30.3}$ & $47.0 / 45.3 / 7.6$ & $\overline{27.4}$ & $53.8 / 37.7 / 8.5$ & $34 \overline{42: 236: 106}$ \\
\hline IL1B & 16944 & $\mathrm{C} / \mathrm{T}$ & patients & $\underline{37.8}$ & $37.2 / 50.0 / 12.8$ & $\underline{38.4}$ & $36.2 / 50.7 / 13.0$ & 35.3 & $41.2 / 47.1 / 11.8$ & $86: 69: 17$ \\
\hline \multirow{2}{*}{ IL2-21 } & \multirow{2}{*}{6822844} & \multirow{2}{*}{$\mathrm{G} / \mathrm{T}$} & patients & $\underline{11.0}$ & $79.1 / 19.8 / 1.2$ & $\underline{12.3}$ & $76.8 / 21.7 / 1.4$ & $\underline{5.9}$ & $88.2 / 11.8 / 0.0$ & $86: 69: 17$ \\
\hline & & & controls & $\overline{12.1}$ & $\overline{78.7 / 18.4 / 2.9}$ & $\overline{12.3}$ & $\overline{78.8 / 17.8 / 3.4}$ & $\overline{11.8}$ & $\overline{78.3 / 19.8 / 1.9}$ & $3 \overline{42: 236: 106}$ \\
\hline \multirow{2}{*}{ IL2RA } & \multirow{2}{*}{2104286} & \multirow{2}{*}{$A / G$} & patients & 16.3 & $70.9 / 25.6 / 3.5$ & 19.6 & $65.2 / 30.4 / 4.3$ & $\underline{2.9}$ & $94.1 / 5.9 / 0.0$ & $86: 69: 17$ \\
\hline & & & controls & $\overline{17.4}$ & $68.4 / 28.4 / 3.2$ & $\overline{16.7}$ & $69.9 / 26.7 / 3.4$ & $\overline{18.9}$ & $\overline{65.1 / 32.1 / 2.8}$ & $34 \overline{42: 236: 106}$ \\
\hline \multirow{2}{*}{ IL6 } & \multirow{2}{*}{1800795} & \multirow{2}{*}{$\mathrm{G} / \mathrm{C}$} & patients & 34.3 & $40.7 / 50.0 / 9.3$ & 37.0 & $36.2 / 53.6 / 10.1$ & 23.5 & $58.8 / 35.3 / 5.9$ & $86: 69: 17$ \\
\hline & & & controls & 34.2 & $42.1 / 47.4 / 10.5$ & 32.8 & $43.2 / 47.9 / 8.9$ & 37.3 & $39.6 / 46.2 / 14.2$ & $342: 236: 106$ \\
\hline \multirow{2}{*}{ IL10 } & \multirow{2}{*}{1800872} & \multirow{2}{*}{$C / A$} & patients & 33.7 & $\underline{43.0 / 46.5 / 10.5}$ & $\underline{30.4}$ & $47.8 / 43.5 / 8.7$ & $\underline{47.1}$ & $23.5 / 58.8 / 17.6$ & $86: 69: 17$ \\
\hline & & & controls & 31.6 & $47.7 / 41.5 / 10.8$ & $\overline{32.6}$ & $\overline{46.2 / 42.4 / 11.4}$ & $\overline{29.2}$ & $50.9 / 39.6 / 9.4$ & $34 \overline{2: 236: 106}$ \\
\hline CTIAA & & & patients & $\underline{34.3}$ & $44.2 / 43.0 / 12.8$ & $\underline{35.5}$ & $40.6 / 47.8 / 11.6$ & $\underline{29.4}$ & $58.8 / 23.5 / 17.6$ & $86: 69: 17$ \\
\hline CILA4 & $308 / 243$ & A & controls & $\overline{34.6}$ & $\overline{42.7 / 45.3 / 12.0}$ & $\overline{36.4}$ & $39.4 / 48.3 / 12.3$ & $\overline{30.7}$ & $\overline{50.0 / 38.7 / 11.3}$ & $34 \overline{42: 236: 106}$ \\
\hline & & & patients & 47.1 & $23.3 / 59.3 / 17.4$ & 47.1 & $23.2 / 59.4 / 17.4$ & 47.1 & $23.5 / 58.8 / 17.6$ & $86: 69: 17$ \\
\hline KB1 & 36249 & I/D & controls & $\overline{44.9}$ & $31.0 / 48.2 / 20.8$ & $\overline{47.2}$ & $28.4 / 48.7 / 22.9$ & $\overline{39.6}$ & $36.8 / 47.2 / 16.0$ & $3 \overline{42: 236: 106}$ \\
\hline & & & patients & $\underline{9.9}$ & $81.4 / 17.4 / 1.2$ & $\underline{10.9}$ & 79.7/18.8/1.4 & $\underline{5.9}$ & $88.2 / 11.8 / 0.0$ & $86: 69: 17$ \\
\hline$P$ & 501 & A & controls & 9.4 & $83.0 / 15.2 / 1.8$ & 9.4 & $82.6 / 16.2 / 1.3$ & 9.4 & $84.0 / 13.2 / 2.8$ & $341: 235: 106$ \\
\hline & & & patients & 44.2 & $29.1 / 53.5 / 17.4$ & 44.9 & $27.5 / 55.1 / 17.4$ & 41.2 & $35.3 / 47.1 / 17.6$ & $86: 69: 17$ \\
\hline & +0336 & & controls & $\overline{43.1}$ & $32.3 / 49.3 / 18.5$ & $\overline{43.2}$ & $32.6 / 48.3 / 19.1$ & $\overline{42.9}$ & $31.4 / 51.4 / 17.1$ & $341: 236: 105$ \\
\hline
\end{tabular}


Supplementary Table 3. Analysis of the distribution of the polymorphic loci alleles and genotypes in patients with Persistent oligoarthritis and in the control group

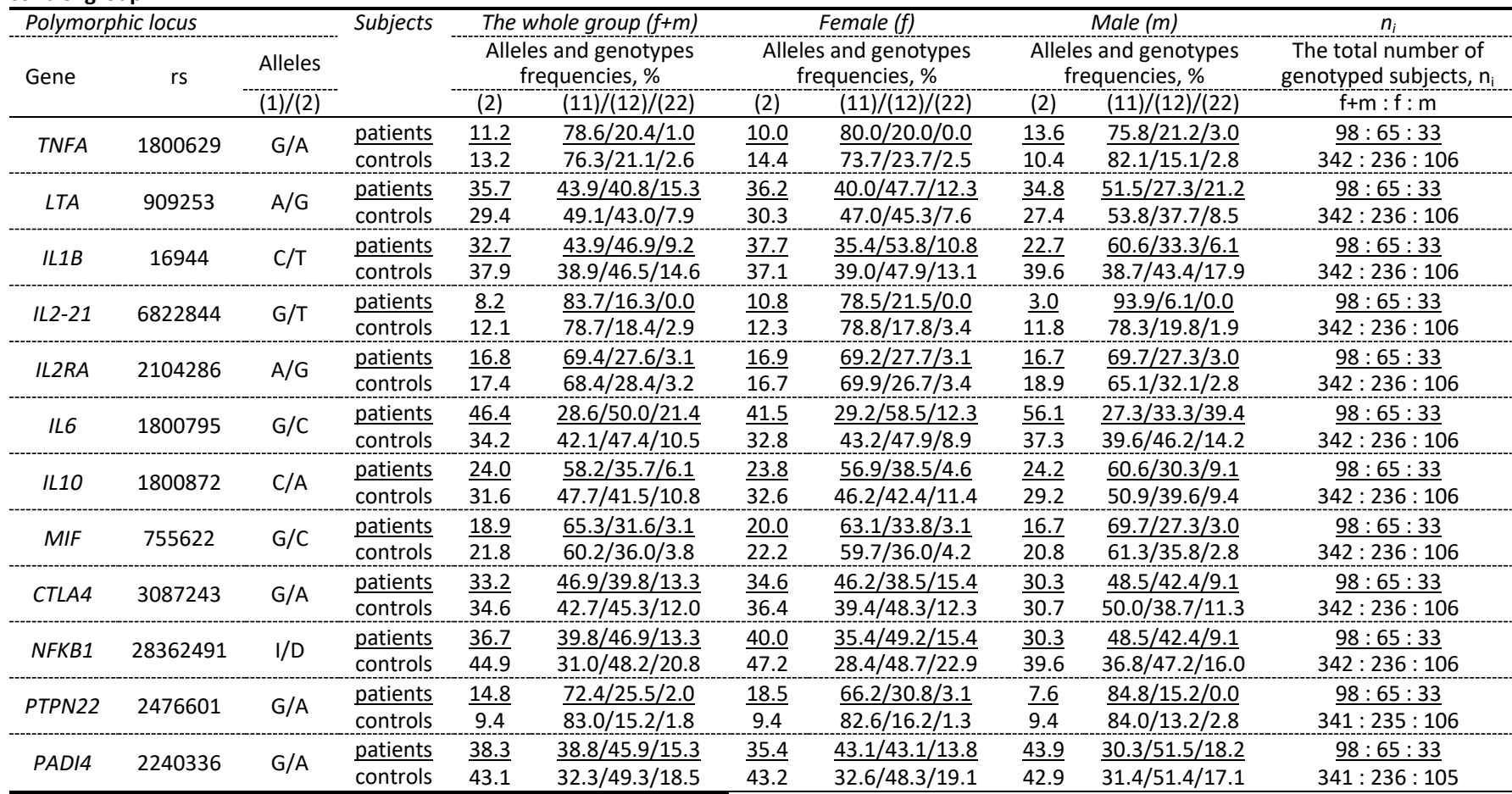

Supplementary Table 4. Analysis of the distribution of the polymorphic loci alleles and genotypes in patients with Extended oligoarthritis and in the control group

\begin{tabular}{|c|c|c|c|c|c|c|c|c|c|c|}
\hline \multicolumn{3}{|c|}{ Polymorphic locus } & \multirow[t]{3}{*}{ Subjects } & \multirow{2}{*}{\multicolumn{2}{|c|}{$\begin{array}{l}\text { The whole group }(f+m) \\
\text { Alleles and genotypes } \\
\text { frequencies, } \%\end{array}$}} & \multirow{2}{*}{\multicolumn{2}{|c|}{$\begin{array}{c}\text { Female }(f) \\
\text { Alleles and genotypes } \\
\text { frequencies, } \%\end{array}$}} & \multicolumn{2}{|r|}{ Male $(m)$} & \multirow{2}{*}{$\begin{array}{c}n_{i} \\
\text { The total number of } \\
\text { genotyped subjects, } n_{i}\end{array}$} \\
\hline \multirow[t]{2}{*}{ Gene } & \multirow[t]{2}{*}{ rs } & \multirow{2}{*}{$\begin{array}{l}\text { Alleles } \\
(1) /(2)\end{array}$} & & & & & & Allele & $\begin{array}{l}\text { and genotypes } \\
\text { quencies, } \%\end{array}$ & \\
\hline & & & & (2) & $(11) /(12) /(22)$ & (2) & $(11) /(12) /(22)$ & $(2)$ & $(11) /(12) /(22)$ & $f+m: f: m$ \\
\hline \multirow{2}{*}{ TNFA } & \multirow{2}{*}{1800629} & \multirow{2}{*}{ G/A } & patients & $\underline{7.6}$ & $84.8 / 15.2 / 0.0$ & $\underline{8.5}$ & $82.9 / 17.1 / 0.0$ & $\underline{0.0}$ & $100.0 / 0.0 / 0.0$ & $46: 41: 5$ \\
\hline & & & controls & $\overline{13.2}$ & $76.3 / 21.1 / 2.6$ & $\overline{14.4}$ & $73.7 / 23.7 / 2.5$ & $\overline{10.4}$ & $82.1 / 15.1 / 2.8$ & $34 \overline{2: 236: 106}$ \\
\hline \multirow[b]{2}{*}{ LTA } & \multirow{2}{*}{909253} & \multirow[b]{2}{*}{$A / G$} & patients & $\underline{31.5}$ & $\underline{50.0 / 37.0 / 13.0}$ & $\underline{32.9}$ & $\underline{48.8 / 36.6 / 14.6}$ & 20.0 & $\underline{60.0 / 40.0 / 0.0}$ & $46: 41: 5$ \\
\hline & & & controls & $\overline{29.4}$ & $49.1 / 43.0 / 7.9$ & $\overline{30.3}$ & $47.0 / 45.3 / 7.6$ & $\overline{27.4}$ & $53.8 / 37.7 / 8.5$ & $34 \overline{2: 236: 106}$ \\
\hline \multirow{2}{*}{$I L 1 B$} & \multirow{2}{*}{16944} & \multirow{2}{*}{$\mathrm{C} / \mathrm{T}$} & patients & $\underline{39.1}$ & $\underline{37.0 / 47.8 / 15.2}$ & 35.4 & $41.5 / 46.3 / 12.2$ & 70.0 & $0.0 / 60.0 / 40.0$ & $46: 41: 5$ \\
\hline & & & controls & $\overline{37.9}$ & $38.9 / 46.5 / 14.6$ & $\overline{37.1}$ & $39.0 / 47.9 / 13.1$ & $\overline{39.6}$ & $38.7 / 43.4 / 17.9$ & $34 \overline{2: 236: 106}$ \\
\hline \multirow{2}{*}{ IL2-21 } & \multirow{2}{*}{6822844} & \multirow{2}{*}{$\mathrm{G} / \mathrm{T}$} & patients & $\underline{4.3}$ & $91.3 / 8.7 / 0.0$ & $\underline{3.7}$ & $92.7 / 7.3 / 0.0$ & $\underline{10.0}$ & $80.0 / 20.0 / 0.0$ & $46: 41: 5$ \\
\hline & & & controls & $\overline{12.1}$ & $78.7 / 18.4 / 2.9$ & $\overline{12.3}$ & $78.8 / 17.8 / 3.4$ & $\overline{11.8}$ & $78.3 / 19.8 / 1.9$ & $34 \overline{2: 236: 106}$ \\
\hline \multirow{2}{*}{ IL2RA } & \multirow{2}{*}{2104286} & \multirow{2}{*}{$A / G$} & patients & $\underline{16.3}$ & 69.6/28.3/2.2 & $\underline{17.1}$ & $68.3 / 29.3 / 2.4$ & $\underline{10.0}$ & $80.0 / 20.0 / 0.0$ & $46: 41: 5$ \\
\hline & & & controls & $\overline{17.4}$ & $68.4 / 28.4 / 3.2$ & $\overline{16.7}$ & $69.9 / 26.7 / 3.4$ & $\overline{18.9}$ & $65.1 / 32.1 / 2.8$ & $34 \overline{2: 236: 106}$ \\
\hline \multirow{2}{*}{ IL6 } & \multirow{2}{*}{1800795} & \multirow{2}{*}{$\mathrm{G} / \mathrm{C}$} & patients & $\underline{38.0}$ & $\underline{34.8 / 54.3 / 10.9}$ & $\underline{40.2}$ & $\underline{31.7 / 56.1 / 12.2}$ & $\underline{20.0}$ & $\underline{60.0 / 40.0 / 0.0}$ & $46: 41: 5$ \\
\hline & & & controls & $\overline{34.2}$ & $42.1 / 47.4 / 10.5$ & $\overline{32.8}$ & $43.2 / 47.9 / 8.9$ & $\overline{37.3}$ & $39.6 / 46.2 / 14.2$ & $34 \overline{2: 236: 106}$ \\
\hline \multirow{2}{*}{ IL10 } & \multirow{2}{*}{1800872} & \multirow{2}{*}{$C / A$} & patients & $\underline{26.1}$ & $\underline{56.5 / 34.8 / 8.7}$ & $\underline{26.8}$ & $\underline{53.7 / 39.0 / 7.3}$ & $\underline{20.0}$ & $80.0 / 0.0 / 20.0$ & $46: 41: 5$ \\
\hline & & & controls & $\overline{31.6}$ & $47.7 / 41.5 / 10.8$ & 32.6 & $46.2 / 42.4 / 11.4$ & 29.2 & $50.9 / 39.6 / 9.4$ & $34 \overline{2: 236: 106}$ \\
\hline & & $\mathrm{G} / \mathrm{C}$ & patients & 17.4 & $67.4 / 30.4 / 2.2$ & 15.9 & $70.7 / 26.8 / 2.4$ & 30.0 & $40.0 / 60.0 / 0.0$ & $46: 41: 5$ \\
\hline IVIIT & 155022 & $\mathrm{G} / \mathrm{C}$ & controls & 21.8 & $60.2 / 36.0 / 3.8$ & 22.2 & $59.7 / 36.0 / 4.2$ & 20.8 & $61.3 / 35.8 / 2.8$ & $342: 236: 106$ \\
\hline & & & patients & $\underline{25.0}$ & $\underline{56.5 / 37.0 / 6.5}$ & 24.4 & $58.5 / 34.1 / 7.3$ & $\underline{30.0}$ & $40.0 / 60.0 / 0.0$ & $46: 41: 5$ \\
\hline CILA4 & $308 / 243$ & $G / A$ & controls & $\overline{34.6}$ & $42.7 / 45.3 / 12.0$ & $\overline{36.4}$ & $39.4 / 48.3 / 12.3$ & 30.7 & $50.0 / 38.7 / 11.3$ & $342: 236: 106$ \\
\hline & & & patients & $\underline{44.6}$ & $\underline{30.4 / 50.0 / 19.6}$ & 45.1 & $31.7 / 46.3 / 22.0$ & $\underline{40.0}$ & $20.0 / 80.0 / 0.0$ & $46: 41: 5$ \\
\hline NFKBI & 28362491 & 1/D & controls & $\overline{44.9}$ & $31.0 / 48.2 / 20.8$ & $\overline{47.2}$ & $28.4 / 48.7 / 22.9$ & $\overline{39.6}$ & $36.8 / 47.2 / 16.0$ & $34 \overline{2: 236: 106}$ \\
\hline & & & patients & $\underline{14.1}$ & $71.7 / 28.3 / 0.0$ & $\underline{15.9}$ & $68.3 / 31.7 / 0.0$ & $\underline{0.0}$ & $100.0 / 0.0 / 0.0$ & $46: 41: 5$ \\
\hline PIPINL2 & $24 / 6601$ & G/A & controls & $\overline{9.4}$ & $83.0 / 15.2 / 1.8$ & $\overline{9.4}$ & $82.6 / 16.2 / 1.3$ & $\overline{9.4}$ & $84.0 / 13.2 / 2.8$ & $34 \overline{1: 235: 106}$ \\
\hline & & & patients & $\underline{51.1}$ & $\underline{23.9 / 50.0 / 26.1}$ & $\underline{51.2}$ & $\underline{24.4 / 48.8 / 26.8}$ & $\underline{50.0}$ & $20.0 / 60.0 / 20.0$ & $46: 41: 5$ \\
\hline PADI4 & 2240336 & $G / A$ & controls & $\overline{43.1}$ & $32.3 / 49.3 / 18.5$ & $\overline{43.2}$ & $32.6 / 48.3 / 19.1$ & $\overline{42.9}$ & $31.4 / 51.4 / 17.1$ & $341: 236: 105$ \\
\hline
\end{tabular}


Supplementary Table 5. Analysis of the distribution of the polymorphic loci alleles and genotypes in patients with Enthesitis related arthritis and in the control group

\begin{tabular}{|c|c|c|c|c|c|c|c|c|c|c|}
\hline \multicolumn{3}{|c|}{ Polymorphic locus } & \multirow[t]{3}{*}{ Subjects } & \multirow{2}{*}{\multicolumn{2}{|c|}{$\begin{array}{l}\text { The whole group }(f+m) \\
\text { Alleles and genotypes } \\
\text { frequencies, } \%\end{array}$}} & \multirow{2}{*}{\multicolumn{2}{|c|}{$\begin{array}{c}\text { Female }(f) \\
\text { Alleles and genotypes } \\
\text { frequencies, \% }\end{array}$}} & \multirow{2}{*}{\multicolumn{2}{|c|}{$\begin{array}{c}\text { Male }(m) \\
\text { Alleles and genotypes } \\
\text { frequencies, } \%\end{array}$}} & \multirow{3}{*}{$\begin{array}{c}n_{i} \\
\text { The total number of } \\
\text { genotyped subjects, } n \\
\mathrm{f}+\mathrm{m}: \mathrm{f}: \mathrm{m}\end{array}$} \\
\hline \multirow[t]{2}{*}{ Gene } & \multirow[t]{2}{*}{ rs } & \multirow{2}{*}{$\begin{array}{l}\text { Alleles } \\
(1) /(2) \\
\end{array}$} & & & & & & & & \\
\hline & & & & $(2)$ & $(11) /(12) /(22)$ & $(2)$ & $(11) /(12) /(22)$ & $(2)$ & $(11) /(12) /(22)$ & \\
\hline TNFA & 1800629 & $\mathrm{G} / \mathrm{A}$ & $\begin{array}{l}\text { patients } \\
\text { controls }\end{array}$ & $\frac{7.1}{13.2}$ & $\frac{85.7 / 14.3 / 0.0}{76.3 / 21.1 / 2.6}$ & $\frac{16.7}{14.4}$ & $\frac{66.7 / 33.3 / 0.0}{73.7 / 23.7 / 2.5}$ & $\frac{5.2}{10.4}$ & $\frac{89.7 / 10.3 / 0.0}{82.1 / 15.1 / 2.8}$ & $\frac{35: 6: 29}{342: 236: 106}$ \\
\hline LTA & 909253 & $A / G$ & $\frac{\text { patients }}{\text { controls }}$ & $\frac{41.4}{29.4}$ & $\frac{22.9 / 71.4 / 5.7}{49.1 / 43.0 / 7.9}$ & $\frac{33.3}{30.3}$ & $\frac{33.3 / 66.7 / 0.0}{47.0 / 45.3 / 7.6}$ & $\frac{43.1}{27.4}$ & $\frac{20.7 / 72.4 / 6.9}{53.8 / 37.7 / 8.5}$ & $\frac{35: 6: 29}{342: 236: 106}$ \\
\hline IL1B & 16944 & $\mathrm{C} / \mathrm{T}$ & $\begin{array}{l}\text { patients } \\
\text { controls }\end{array}$ & $\frac{40.0}{37.9}$ & $\frac{42.9 / 34.3 / 22.9}{38.9 / 46.5 / 14.6}$ & $\frac{33.3}{37.1}$ & $\frac{50.0 / 33.3 / 16.7}{39.0 / 47.9 / 13.1}$ & $\frac{41.4}{39.6}$ & $\frac{41.4 / 34.5 / 24.1}{38.7 / 43.4 / 17.9}$ & $\frac{35: 6: 29}{342: 236: 106}$ \\
\hline IL2-21 & 6822844 & $\mathrm{G} / \mathrm{T}$ & $\frac{\text { patients }}{\text { controls }}$ & $\frac{5.7}{12.1}$ & $\frac{88.6 / 11.4 / 0.0}{78.7 / 18.4 / 2.9}$ & $\frac{8.3}{12.3}$ & $\frac{83.3 / 16.7 / 0.0}{78.8 / 17.8 / 3.4}$ & $\frac{5.2}{11.8}$ & $\frac{89.7 / 10.3 / 0.0}{78.3 / 19.8 / 1.9}$ & $\frac{35: 6: 29}{342: 236: 106}$ \\
\hline IL2RA & 2104286 & $A / G$ & patients & $\frac{17.1}{17.4}$ & $\frac{68.6 / 28.6 / 2.9}{68.4 / 28.4 / 3.2}$ & $\frac{25.0}{16.7}$ & $\frac{50.0 / 50.0 / 0.0}{69.9 / 26.7 / 3.4}$ & $\frac{15.5}{18.9}$ & $\frac{72.4 / 24.1 / 3.4}{65.1 / 32.1 / 2.8}$ & $\begin{array}{c}35: 6: 29 \\
342: 236: 106\end{array}$ \\
\hline IL6 & 1800795 & $\mathrm{G} / \mathrm{C}$ & patients & $\frac{38.6}{34.2}$ & $\frac{45.7 / 31.4 / 22.9}{42.1 / 47.4 / 10.5}$ & $\frac{33.3}{32.8}$ & $\frac{50.0 / 33.3 / 16.7}{43.2 / 47.9 / 8.9}$ & $\frac{39.7}{37.3}$ & $\frac{44.8 / 31.0 / 24.1}{39.6 / 46.2 / 14.2}$ & $\frac{35: 6: 29}{342: 236: 106}$ \\
\hline IL10 & 1800872 & C/A & patients & $\frac{37.1}{31.6}$ & $\frac{42.9 / 40.0 / 17.1}{47.7 / 41.5 / 10.8}$ & $\frac{33.3}{32.6}$ & $\frac{50.0 / 33.3 / 16.7}{46.2 / 42.4 / 11.4}$ & $\frac{37.9}{29.2}$ & $\frac{41.4 / 41.4 / 17.2}{50.9 / 39.6 / 9.4}$ & $\frac{35: 6: 29}{342: 236: 106}$ \\
\hline MIF & 755622 & $\mathrm{G} / \mathrm{C}$ & $\begin{array}{l}\text { patients } \\
\text { controls }\end{array}$ & $\frac{14.3}{21.8}$ & $\frac{74.3 / 22.9 / 2.9}{60.2 / 36.0 / 3.8}$ & $\frac{8.3}{22.2}$ & $\frac{83.3 / 16.7 / 0.0}{59.7 / 36.0 / 4.2}$ & $\frac{15.5}{20.8}$ & $\frac{72.4 / 24.1 / 3.4}{61.3 / 35.8 / 2.8}$ & $\frac{35: 6: 29}{342: 236: 106}$ \\
\hline CTLA4 & 3087243 & $\mathrm{G} / \mathrm{A}$ & $\frac{\text { patients }}{\text { controls }}$ & $\frac{32.9}{34.6}$ & $\frac{45.7 / 42.9 / 11.4}{42.7 / 45.3 / 12.0}$ & $\frac{16.7}{36.4}$ & $\frac{66.7 / 33.3 / 0.0}{39.4 / 48.3 / 12.3}$ & $\frac{36.2}{30.7}$ & $\frac{41.4 / 44.8 / 13.8}{50.0 / 38.7 / 11.3}$ & $\frac{35: 6: 29}{342: 236: 106}$ \\
\hline NFKB1 & 28362491 & I/D & patients & $\frac{52.9}{44.9}$ & $\frac{28.6 / 37.1 / 34.3}{31.0 / 48.2 / 20.8}$ & $\frac{50.0}{47.2}$ & $\frac{33.3 / 33.3 / 33.3}{28.4 / 48.7 / 22.9}$ & $\frac{53.4}{39.6}$ & $\frac{27.6 / 37.9 / 34.5}{36.8 / 47.2 / 16.0}$ & $\begin{array}{c}35: 6: 29 \\
342: 236: 106\end{array}$ \\
\hline PTPN22 & 2476601 & $\mathrm{G} / \mathrm{A}$ & patients & $\frac{18.6}{9.4}$ & $\frac{65.7 / 31.4 / 2.9}{83.0 / 15.2 / 1.8}$ & $\frac{25.0}{9.4}$ & $\frac{66.7 / 16.7 / 16.7}{82.6 / 16.2 / 1.3}$ & $\frac{17.2}{9.4}$ & $\frac{65.5 / 34.5 / 0.0}{84.0 / 13.2 / 2.8}$ & $\begin{array}{c}35: 6: 29 \\
341: 235: 106\end{array}$ \\
\hline PADI4 & 2240336 & $\mathrm{G} / \mathrm{A}$ & $\frac{\text { patients }}{\text { controls }}$ & $\frac{51.4}{43.1}$ & $\frac{22.9 / 51.4 / 25.7}{32.3 / 49.3 / 18.5}$ & $\frac{58.3}{43.2}$ & $\frac{16.7 / 50.0 / 33.3}{32.6 / 48.3 / 19.1}$ & $\frac{50.0}{42.9}$ & $\frac{24.1 / 51.7 / 24.1}{31.4 / 51.4 / 17.1}$ & $\frac{35: 6: 29}{341: 236: 105}$ \\
\hline
\end{tabular}

